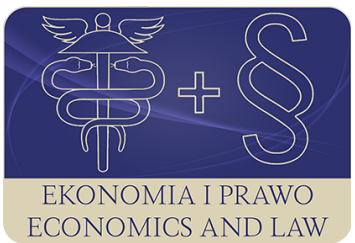

EKONOMIA I PRAWO. ECONOMICS AND LAW

Volume 20, Issue 1, March 2021

p-ISSN 1898-2255, e-ISSN 2392-1625

www.economicsandlaw.pl

ORIGINAL ARTICLE

received 03.06.2020; revised 20.03.2021; accepted 31.03.2021

Citation: Nowacka, A., Szewczyk-Jarocka, M., \& Zawiślińska, I. (2021). Socio-demographic determinants of financial exclusion of the unemployed on the local labour market: a case study. Ekonomia i Prawo. Economics and Law, 20(1): 155-171. doi:10.12775/EiP.2021.010.

\title{
Socio-demographic determinants of financial exclusion of the unemployed on the local labour market: a case study
}

\author{
ANNA NOWACKA \\ corresponding author \\ The Mazovian State University in Płock, Faculty of Economic Sciences and Information Technology, \\ ul. Gałczyńskiego 28, 09-402 Płock, Poland \\ $\square$ a.nowacka@mazowiecka.edu.pl \\ (D) orcid.org/0000-0001-9300-3646 \\ MARIOLA SZEWCZYK-JAROCKA
}

The Mazovian State University in Płock, Faculty of Economic Sciences and Information Technology, Poland

$\square$ m.szewczyk-jarocka@mazowiecka.edu.pl

(D) orcid.org/0000-0001-9048-9513

\section{IZABELA ZAWIŚLIŃSKA}

SGH Warsaw School of Economics, Collegium of Socio-Economics, Poland

ఐizawis@sgh.waw.pl

D orcid.org/0000-0003-4318-7285

\begin{abstract}
Motivation: People who experience problems accessing financial products and services in a suitable form cannot fully participate in economic and social lives. The groups particularly vulnerable to financial exclusion in the area of banking services and saving products are the unemployed.

Aim: The aim of the study is to determine the relationship between socio-demographic determinants and selected areas of financial exclusion related to banking usage and the propensity to save. The empirical basis of the issues raised in this article is the study of the literature and the findings of the survey conducted among 350 unem-
\end{abstract}


ployed persons registered at the Municipal Labour Office in Płock in the period from September to October 2018.

Results: Education, age, reasons and the period of registration at the labour office exert an impact on the selected areas of financial exclusion of the unemployed regarding the bank usage and the propensity to save. The results of the study indicate that on the local market education was the feature that most determined the degree of banking usage, the refusal

to conduct banking services or the propensity to save among the unemployed.

Keywords: financial exclusion; banking usage; attitudes towards saving; the unemployed JEL: G21; G40; D14

\section{Introduction}

The concept of financial exclusion was first used in 1993 by the geographers Leyshon and Thrift (1993) in the work on the geographical conditions of financial exclusion in the United States and Great Britain. The authors of the study defined financial exclusion as: "processes that cause obstacles to the access to the financial market for specific social groups or individuals." In turn, the European Commission (2008) defines financial exclusion as a situation in which a person encounters difficulties in accessing and/ or using financial services and products to the extent that meets their needs and enables them to lead a regular social life. It is also important to perceive the phenomenon of financial exclusion as a gradual disaffiliation (isolation) from the financial service market, e.g. due to the offer not matching the client's needs, low income or financial problems (Achugamonu et al., 2020; Kata \& Walenia 2015; MetLife Foundation \& Microfinance Centre, 2014).

While referring to the issue of financial exclusion, a distinction between two seemingly similar words should be marked, i.e., access and use. 'Access' essentially refers to the supply of financial services, whereas 'use' is determined by demand as well as supply (World Bank, 2014).

In numerous publications on financial exclusion, the phenomenon is perceived through an access to a bank account. Such an approach is restricted to transactional banking exclusion. It is important to remember that financial exclusion entails restrictions in the areas of savings, crediting and insurance. Therefore, there are more specific types of it distinguished in the literature, namely: savings, credit, payment, investment, insurance and pension exclusion (Domańska-Szaruga, 2015).

The group that is especially vulnerable to financial exclusion is the unemployed who live on savings, if they have some, on benefits, subsidies, are family dependent and/ or derive income from unregistered work. The lack of regular income or inability to document it becomes a serious obstacle to using financial services such as: loans, borrowings, opening a bank account or conducting financial operations (Mylonidis et al., 2019). Low incomes prevent households from taking action to improve the quality of life. At the same time, it should be noticed that barriers in accessing financial services faced by persons affected by 
financial marginalization are also caused by alternative choices offered by quasi-banking institutions (Warchlewska, 2013), which often operate in the market segment unsupported by banks and in conditions of reduced competition. That may contribute to aggravation of financial exclusion of certain groups, including the unemployed, for example through a growing spiral of debt (especially when using the so-called payday loans) and limited confidence in financial institutions.

In the opinion of the authors of this article, both such a definition and classification of financial exclusion constitute an impulse for discussion and analysis of its particular areas and an attempt to indicate the relationship between the socio-demographic determinants of the unemployed and the degree of banking usage and their saving propensity.

\section{Literature review}

\subsection{Banking usage term}

Specifying the precise and homogeneous definition of banking usage is highly difficult. It should be emphasized that this concept is often referred to ways of measuring the use of banking services. That is why, the literature on the subject includes: the indicator of banking usage, the indicator of the availability of banking services or the indicator of using banking services. The scope and frequency of using banking services, known as banking penetration, have raised the interest not only of banks and other financial institutions, but also of the world of science ${ }^{1}$. The issue has become an important thematic area of conferences and symposia and the subject of a variety of scientific studies.

Banking usage can be graded in accordance with the scope and the intensity of use of various types of services by the consumers (Breitbach \& Walstad, 2014; Polasik \& Piotrowska, 2014). That is why, the European Commission (2008) draws attention to several levels of banking based on the degree of financial exclusion (Kurczewska, 2011):

- the first applies to people who do not use banking services at all;

- the second refers to persons who have a bank account but do not use many of its options, e.g. they do not use electronic banking services or payments or credit cards;

- the third is associated with people who have access to a wide range of banking services, but these services are not fully adapted to their needs or socio-economic status.

On the other hand, the National Bank of Poland reports present a slightly different approach to the issue, based on the identification of cashless levels (Tochmański, 2013) but also taking into account the activity of using payment instruments (Koźliński, 2013). In turn, Maison (2013) distinguishes three lev-

${ }^{1}$ Further on banking in: Christopher (2015); Klawitter \& Fletschner (2011); Szopiński (2019). 
els of advancement in banking usage. The first level indicates having a bank account, the second — using payment cards, and the third — making cashless payments.

The literature proposes a fairly coherent definition of banking usage by the people who, presented as a group, do not use any type of bank account (checking or savings) or other banking services, including credit (Grimes et al., 2010; Hogarth et al., 2005; Paulson et al., 2008; Rhine et al., 2006). It is a little more complicated to define a group of insufficient banking usage (in other words: marginally banked people). On the one hand, the use of a bank account without its electronic banking functionality is indicated. In other studies, however, those people are defined as having limited access to banking services, not only those related directly to the account. Kuchciak (2012) notes that measuring banking usage only on the basis of having a bank account is a too narrow approach. That is why, she proposes to set levels of banking usage that would cover a wider range of banking services (FDIC, 2009):

- unbanked persons - those who have no bank account thus no contact with the banking sector;

- marginal banking usage persons - those who have limited access to banking services (e.g. loans) or use them sporadically (e.g. once a month withdrawing all funds from the account);

- banking usage persons - those who use a wide range of banking services. On the basis of the given definitions, the authors suggest the following systematic division of the levels of banking usage covering a wider range of services (Scheme 1).

This classification is the basis for further considerations, especially with regard to the presentation of research findings.

\subsection{Attitudes towards saving as a determinant of exclusion}

Saving means deferring consumption over time that requires certain sacrifices and restrictions on current lifestyles as well as self-discipline. On one hand, people who have low income or have lost their jobs may have difficulty in accumulating savings. On the other, a certain tendency to excessive borrowing, which predominates the propensity to save can be observed (Zmudzińska, 2016). Lack of trust in banks or financial institutions and the associated cult of cash can also be a certain obstacle to putting aside funds for the future. It may stem from a lack of know-how or a lack of financial competences, as de Bassa Scheresberg (2013) emphasizes that financial awareness may be associated with accumulating precautionary savings.

Those who do not possess a checking or saving account or do not use any banking services can be stand for determinants of exclusion from the saving system. However, it should be noticed that clients can use various forms of saving, also outside the banking system. In this case, it is difficult to consider the whole group as excluded (Czarnecka, 2018). Another reason for exclusion 
from the saving system may be refraining from electronic banking, in particular from the functionality of the online bank accounts which creates possibilities for flexible forms of saving. A basic saving account with a low level of technological sophistication can reduce the number of customers using banking products ${ }^{2}$.

\section{Organisation of the research process}

\subsection{Research goal and hypotheses}

Many authors point at the influence of socio-economic factors, i.e. education, career and income in relation to the level of household banking usage (Rhine \& Greene, 2006; Rhine et al., 2006). Therefore, the main goal of the study is to determine the impact of socio-demographic determinants on the selected areas of financial exclusion, related to banking usage and saving propensity with reference to the local labour market. In view of the topicality of the issues undertaken, the analysis of the subject literature and the presented research goal, there have been the following hypotheses formulated:

- Hl. Socio-demographic determinants define the scope of using banking services;

- H2. Attitudes towards saving are related to socio-demographic determinants;

- H3. Refusal to access banking services depends on socio-demographic determinants;

Empirical material used to verify the hypotheses was collected by means of a questionnaire conducted on research subjects locally.

\subsection{Research methods and scope}

The empirical study was conducted in form of the questionnaire. The target group were the unemployed registered in the Municipal Labour Office in Ptock. As of the end of August 2018, 4319 people were registered as unemployed by the Municipal Labour Office in Ptock (2018). In total, 350 unemployed people were covered by the research, composing a representative sample which allowed to conclude about the entire population of the unemployed in Ptock as to the accuracy of $5 \%$. The subjects participating in the questionnaire were selected by the use of the convenient sampling method (Hill \& Alexander, 2003). The unemployed who expressed their willingness to answer the questions were asked to fill in the questionnaire conducted between September and October 2018.

2 Further on savings accounts in the formal banking system in Barnerjee \& Duflo (2011). 


\subsection{Methods of inference and processing of the research results}

The value of 0.05 was conventionally assumed to be the threshold of statistical significance. The statistical significance of the analysed relationships was examined on the basis of the likelihood ratio, which is used to analyse relationships between category variables, i.e. those that divide the examined people into groups in a situation when some of the distinguished categories are not numerous. Statistically significant relationships were supplemented with the values of Cramer's V effect strength measure. The interpretation of the value of this measure depends on the number of subjects and the number of groups under comparison. At one liberty degree, the weak effect is indicated by value equal to 0.10 , the average effect by value equal to 0.30 and the strong effect by value equal to 0.50 . At two liberty degrees, the weak effect is indicated by value equal to 0.07 , the average effect by value equal to 0.21 and the strong effect by value equal to 0.35 . At three liberty degrees, the weak effect is indicated by value equal to 0.06 , the average effect by value equal to 0.17 and the strong effect by value equal to 0.29 . At four liberty degrees, the weak effect is indicated by a value of value equal to 0.05 , the average effect by value equal to 0.15 and the strong effect by value equal to 0.25 . At five liberty degrees, the weak effect is indicated by a value of value equal to 0.04 , the average effect by value equal to 0.13 and the strong effect by value equal to 0.22 . The greater the number of liberty degrees, the lower the thresholds of Cramer's V measure, above which the effect is considered weak, average or strong.

\section{Presentation of research results}

\subsection{Verification of the Hl hypothesis}

In order to verify hypothesis 1, a single-choice question: "Are you a customer of a bank?" and a multiple-choice question: "What banking products do you use?". The set of answers included the following options: 1) checking-savings account 2) commercial credit 3) term deposits 4) insurance 5) bank (payment) cards 6) electronic banking. The next question concerned the following socio-demographic characteristics: age, education, gender, reasons and period of registration with the labour office.

Two hundred and ninety-two people surveyed (83.4\%) were bank customers. Based on the values of the likelihood ratio, no statistically significant relations between being a bank customer and gender: $\chi(2)=4.01, p>0.05$ nor reasons for registering with the labour office: $\chi(10)=8.85, p>0.05$ were found. On the other hand, statistically significant relations between being a bank customer and age: $\chi(8)=24.97, \mathrm{p}<0.01, \mathrm{~V}(8)=0.19$, $\mathrm{p}<0.01$; education: $\chi(6)=14.84$, $\mathrm{p}<0.05, \mathrm{~V}(6)=0.15, \mathrm{p}<0.05$ and the length of the registration period at the labour office: $\chi(4)=10.35, p<0.05, V(4)=0.12, p<0.05$ were found. On the basis 
of the above analysis it can be stated that people who were members of the oldest age group $(69.4 \%)$, people with primary or basic vocational education $(73.1 \%)$ and people with a long registration period at the labour office (79.3\%) were the least frequent to be a bank customer (Chart 1).

The basic banking service used by customers is a personal account, i.e. a checking-saving account. It is the basis for making settlements and collecting funds. Having a personal account enables using various forms of electronic banking (payment cards, Internet or mobile banking), taking a loan, making a deposit and using insurance services.

Therefore, the respondents were asked about the scope of banking services they use. Among a set of socio-demographic characteristics, statistically significant relationships were found between the scope of banking services and the following determinants: age, education, registration period and reasons for registration in Płock. The results of the analysis are presented in Table 1.

The presented results indicate that gender has no influence on the extent of the use of banking services, unlike other control variables. For the youngest respondents, bank accounts, loans and term deposits were the least frequently picked, while for the oldest respondents - payment cards and electronic banking. On the other hand, people with higher education and shorter period of registration at the Municipal Labour Office used a wide range of products more often with exception to payment cards. The distribution of answers in case of reasons for registration in the labour office is interesting. Bank accounts and payment cards were picked the least frequently by people made redundant due to closing down their workplace, commercial credits - by graduates, term deposits - by people looking for a better paid job, insurance - by people dismissed from work, e-banking - by people dismissed from work in groups.

The analysis of the questionnaire results allows to state that there is a correlation between certain socio-demographic determinants (age, education, period and reasons for registering in the labour office) and the scope of using banking services. It should be added that the strength of the obtained effect was moderate. No statistically significant correlation was found for the "gender" determinant. Therefore, the $\mathrm{Hl}$ hypothesis can be considered true and it can be concluded that socio-demographic determinants define the scope of use of banking services by the unemployed in the local labour market.

\subsection{Verification of the $\mathrm{H} 2$ hypothesis}

Two questions were used to verify the $\mathrm{H} 2$ hypothesis. The first one was: "Do you think it is worth saving money for the future?". The set of answer contained the following options: (1) definitely yes; (2) rather yes; (3) rather no; (4) definitely no; (5) difficult to say. The latter question concerned the following socio-demographic variables: age, education, gender, reasons and period of registration at the labour office. The distribution of answers indicates a fairly common perception of the need to save for the future (Table 2). 
The answers "definitely yes" and "rather yes" represented $89.1 \%$ of the general opinion. The analysis of the research findings indicated that socio-demographic variables, i.e. age, gender, reasons and the period of registration in the labour office are not statistically significant factors that influence the opinion on saving for the future. The only statistically significant correlation obtained was for the "education" determinant. People with higher education were more convinced that it is worth saving for the future, whereas the group of people with primary or vocational education most often demonstrated an undecided attitude (Chart 2). The obtained effect was strong $\mathrm{V}(15)=0.18, \mathrm{p}<0.01$.

In conclusion, it should be noticed that the presented results do not allow the H2 hypothesis to be considered true. This means that socio-demographic determinants, i.e. age, gender, reasons and the period of registration at the labour office are not related to attitudes towards saving for the future among the unemployed in the local labour market. It cannot be ignored, however, that as the level of education increases, the awareness of the need to save grows.

\subsection{Verification of the H3 hypothesis}

The third hypothesis was verified on the basis of the questions: "Has it ever happened that the bank refused its services to you? (yes/ no)" and "What banking services were you refused?". The set of answer contained the following options: (1) bank credit, (2) loan, (3) starting a bank account, (4) issuing a debit card assigned to the account. Another question concerned the following socio-demographic variables: age, education, sex, grounds for and the term of registering at the labour office.

The bank refused to provide services to 90 respondents (25.7\%). Statistically significant relationships between refusal to provide banking services and age: $(\lambda(8)=23.28, \mathrm{p}<0.01, \mathrm{~V}(8)=0.17, \mathrm{p}<0.01)$ and education: $(\lambda(6)=26.65$, $\mathrm{p}<0.001, \mathrm{~V}(6)=0.15, \mathrm{p}<0.05)$ were obtained. The strength of the obtained results was moderate.

Individuals found in the youngest group with higher education were refused the most rarely while individuals from the age group of 36-45 with primary and vocational education were refused most frequently. There is a detailed distribution of the answers provided by the respondents, including different categories of bank services, which are presented in Chart 3. Clients were most frequently refused to be provided with bank credit $-24.9 \%$ of all the answers and loan $-19.4 \%$. The distribution of the answers is visible in Table 3.

The analysis of test results indicated that only education and grounds for registering at the labour office have a statistically significant impact on the distribution of the answers. The relationships between the education and refusal to provide a bank credit $\mathrm{V}(6)=0.16, \mathrm{p}<0.01$; refusal to provide a loan $\mathrm{V}(6)=0.15$, $\mathrm{p}<0.05$; refusal to open a bank account $\mathrm{V}(6)=0.16, \mathrm{p}<0.01$, refusal to issue a debit card assigned to the account $\mathrm{V}(6)=0.17, \mathrm{p}<0.01$ as well as the relationship between the grounds for registering at the labour office and refusal to provide 
a loan $\mathrm{V}(10)=0.17, \mathrm{p}<0.05$. The strength of the obtained results was moderate. Persons with basic or vocational level of education were refused bank services most often, including: bank credits $-34.4 \%$, loans $-26.9 \%$, opening a bank account $-7.5 \%$, issuing a debit card $-6.5 \%$ of all the respondents. Detailed results are presented in Chart 4 . In Chart 5 the percentage distribution of answers given by the respondents who were refused bank services due to their loss of employment (27.1\%) and employment redundancy (29.5\%) are provided.

In conclusion, it has to be stated that the presented results of the research allow the partial verification of the H3 hypothesis, which means that socio-demographic determinants such as age, sex and the term of registration at the labour office do not have impact on the refusal to provide banking services. However, "education" and partially "grounds for registering at labour office" influence the access to the bank services by the unemployed in the local labour market.

\section{Conclusion}

The purpose of this article is to verify the validity of three hypotheses on the basis of a number of publications on the subject concerning the broadly understood problem of current financial exclusion covering different areas. The hypotheses are:

- Hl. Socio-demographic determinants define the range of banking services;

- H2. Approach to saving money is connected to socio-demographic determinants;

- H3. Refusal to provide banking services depends on socio-demographic determinants.

The research methods applied together with the empirical data collected in the questionnaire survey allow partial, yet positive, verification of hypotheses. On that basis, it can be assumed that the main goal is accomplished because it has been proven that socio-demographic determinants exert impact on the chosen areas of financial exclusion connected with banking and the tendency to save money among the unemployed in the local labour market.

Age, education, sex, length of time of registration and reasons for registration at the Municipal Labour Office were taken as control variables. Their connection with exclusion area differs and is dependent on the aspect of phenomenon examination. While in narrow understanding of bank exclusion defined as being or not being a client of a bank, the age, education, length of time of registration at the Labour Office have been pointed out, in case of the range of banking services statistical significance of a relation with all the variables except sex has been shown. Summarizing, it means that bank exclusion tends to touch the elderly with primary or vocational education who were registered in Labour Office for a longer period of time.

Furthermore, it is noteworthy that people with primary or vocational education as well as people collectively dismissed are more likely to experience the refusal of banking services. At the same time, the research results indicate 
that the approaches to saving money differ with regard to the level of education. The unemployed of higher education more often saw the need for saving money.

What is interesting, sex turned to be out of the control variables. None of the areas analysed demonstrated a statistical impact that sex of the unemployed would exert banking usage, refusal to provide the banking services or approach to saving money, which may indicate that there is no such relation.

In conclusion, it is worth emphasizing that education is the determinant that influences the range of provided banking services, approaches to saving money by the unemployed and the reasons for refusing bank service the most. In the light of the obtained results and taking into consideration not only education but also the financial know-how of the respondents, reasons for and the results of financial exclusion, it seems to be intentional.

\section{References}

Achugamonu, U.B., Adetiloye, K.A., Adegbite, E.O., Babajide, A.A., \& Akintola, F.A. (2020). Financial exclusion of bankable adults: implication on financial inclusive growth among twenty-seven SSA countries. Cogent Social Sciences, 6(1). doi:10.1080/23311886.2020.1730046.

Barnerjee, A., \& Duflo, E. (2011). Poor economics: a radical rethinking of the way to fight global poverty. New York: PublicAffairs.

Breitbach, E., \& Walstad, W.W. (2014). Financial literacy and banking affiliation: results for the unbanked, underbanked, and fully banked. Perspectives on Economic Education Research, 9(1).

Christopher, C.M. (2015), Mobile banking: the answer for the unbanked in America. Catholic University Law Review, 65(2).

Czarnecka, M. (2018). Wykluczenie finansowe i integracja finansowa: aspekty terminologiczne. Kwartalnik Kolegium Spoteczno-Ekonomicznego. Studia i Prace, 1. doi:10.33119/kkessip.2018.1.4.

de Bassa Scheresberg, C. (2013). Financial literacy and financial behavior among young adults: evidence and implications. Numeracy, 6(2). doi:10.5038/1936-4660.6.2.5.

Domańska-Szaruga, B. (2015). Wybrane aspekty wykluczenia kredytowego w świetle założeń zrównoważonego rozwoju. Prace Naukowe Uniwersytetu Ekonomicznego we Wroctawiu, 378. doi:10.15611/pn.2015.378.07.

European Commission. (2008). Financial services provision and prevention of financial exclusion. Retrived 18.04.2020 from https://www.bristol.ac.uk.

FDIC. (2009). National survey of unbanked and underbanked households. Retrived 20.03.2020 from https://www.fdic.gov.

Grimes, P.W., Rogers, K.E., Smith, R.C. (2010). High school economic education and access to financial services. Journal of Consumer Affairs, 44(2). doi:10.1111/j.1745-6606.2010.01171.x.

Hill, N., \& Alexander, J. (2003). Pomiar satysfakcji i lojalności klientów. Kraków: Oficyna Ekonomiczna. 
Hogarth, J.M., Anguelov, C.E., \& Lee, J. (2005). Who has a bank account: exploring changes over time, 1989-2001. Journal of Family and Economic Issues, 26(1). doi:10.1891/1052-3073.27.2.231.

Kata, R., \& Walenia, A. (2015). Financial exclusion of farmers and rural entrepreneurs. Journal of Agribusiness and Rural Development, 9(2). doi:10.17306/ jard.2015.24.

Klawitter, M., \& Fletschner, D. (2011), Who is banked in low income families: the effects of gender and bargaining power. Social Science Research, 40(1). doi:10.1016/j.ssresearch.2010.02.002.

Koźliński, T. (2013). Zwyczaje ptatnicze Polaków. Retrived 20.03.2020 from https://www.nbp.pl.

Kuchciak, I. (2012). Innowacyjne koncepcje ubankowienia społeczeństwa. Acta Universitatis Lodziensis. Folia Oeconomica, 266.

Kurczewska, A. (2011). Społeczna odpowiedzialność instytucji mikrokredytowych w Europie. In B. Mikołajczyk, \& A. Kurczewska (Ed.). Mikrokredyty $w$ Europie sposobem na pobudzenie przedsiębiorczości i walkę z wykluczeniem spotecznym. Warszawa: Difin.

Leyshon, A., \& Thrift, N. (1995). Geographies of financial exclusion: financial abandonment in Britain and the United States. Transactions of the Institute of British Geographers, 20(3). doi:10.2307/622654.

Maison, D. (2013). Postawy Polaków wobec obrotu bezgotówkowego: raport z badania 2013 i analiza porównawcza z danymi 2009 roku. Retrived 20.03.2020 from http://www.nbp.pl.

MetLife Foundation \& Microfinance Centre. (2014). Wtączenie finansowe w Polsce. Retrived 18.04.2020 from https://mfc.org.pl.

Municipal Labour Office in Płock. (2018). Sprawozdanie o rynku pracy 01.0831.08.2018. Retrived 05.01.2020 from: http://mupplock.praca.gov.pl.

Mylonidis, N., Chletsos M., \& Barbagianni V. (2019). Financial exclusion in the USA: looking beyond demographics. Journal of Financial Stability, 40. doi:10.1016/j.jfs.2017.09.004.

Paulson, A., Sherrie, L., \& Rhine, W. (2008). The financial assimilation of an immigrant group: evidence on the use of checking and savings accounts and currency exchanges. Journal of Family and Economic Issues, 29(2). doi:10.1007/s10834-008-9097-8.

Polasik, M., \& Piotrowska, A. (2014). Transakcyjne wykluczenie finansowe w Polsce w świetle badań empirycznych. Prace Naukowe Uniwersytetu Ekonomicznego we Wroctawiu, 330. doi:10.15611/pn.2014.330.34.

Rhine, S.L.W., Greene, W.H. (2006). The determinants of being unbanked for U.S. immigrants. Journal of Consumer Affairs, 40(1). doi:10.1111/j.1745-6606.2006.00044.x.

Rhine, S.L.W., Greene, W.H., \& Toussaint-Comeau, M. (2006). The importance of check-cashing businesses to the unbanked: racial/ethnic differences. Review of Economics and Statistics, 88(1). doi:10.1162/003465306775565846. 
Szopiński, T. (2019), Who is unbanked: evidence from Poland. Contemporary Economics, 13(4). doi:10.5709/ce.1897-9254.323.

Tochmański, A. (2013). Rachunek, karta i Internet: drzwi i klucze do naszych finansów. Paper presented at the conference "Dostępne finance”, NBP.

Warchlewska, A. (2013). Rola instytucji parabankowych w kwestii przeciwdziałania wykluczeniu finansowemu na przykładzie spółdzielczych kas oszczędnościowo-kredytowych. Studia Ekonomiczne, 173.

World Bank. (2014). Global financial development report 2014: financial inclusion. Retrived 20.03.2021 from https://openknowledge.worldbank.org.

Zmudzińska, I. (2016). Postawy Polaków wobec systematycznego i długoterminowego oszczędzania. In J. Rutecka-Góra (Ed.), Dtugoterminowe oszczędzanie: postawy, strategie i wyzwania. Warszawa: Oficyna Wydawnicza SGH.

\section{Acknowledgements}

Author contributions: authors have given an approval to the final version of the article. Authors contributed to this work as follows: A.N., M.S-J. and I.Z developed the concept and designed the study, A.N. collected the data, A.N. and M.S-J. analysed and interpreted the data, A.N. and M.S-J prepared draft of article, I.Z. revised the article critically for important intellectual content.

Funding: this research was funded by the city of Płock in connection with the competition of the Mayor of the city of Ptock for financing research grants realized within the task Cooperation with universities (20/WEK-I/Z/607/2019). 


\section{Appendix}

\section{Table 1.}

The analysis of the corelation between socio-demographic determinants (sex, age, education, term of and grounds for registering at the labour office) and the scope of accessing bank services

\begin{tabular}{llcccc}
\hline $\begin{array}{c}\text { Sociodemographic } \\
\text { determinants }\end{array}$ & The scope of bank services & $\chi$ & $\mathrm{df}$ & $\mathrm{p}$ & $\begin{array}{c}\text { Statistically significant } \\
\text { corelation }\end{array}$ \\
\hline sex & checking and saving account & 4.56 & 2 & 0.102 & none \\
& commercial credit & 4.79 & 2 & 0.091 & none \\
& fixed-term deposit & 4.10 & 2 & 0.129 & none \\
& insurance & 4.72 & 2 & 0.095 & none \\
& debit cards & 3.99 & 2 & 0.136 & none \\
& electronic banking & 4.27 & 2 & 0.119 & none \\
\hline age & checking and saving account & 45.10 & 8 & 0.001 & $\mathrm{~V}(8)=0.26, \mathrm{p}<0.001$ \\
& commercial credit & 39.23 & 8 & 0.001 & $\mathrm{~V}(8)=0.23, \mathrm{p}<0.001$ \\
& fixed-term deposit & 27.99 & 8 & 0.001 & $\mathrm{~V}(8)=0.20, \mathrm{p}<0.001$ \\
& insurance & 27.25 & 8 & 0.001 & $\mathrm{~V}(8)=0.20, \mathrm{p}<0.001$ \\
& debit cards & 28.68 & 8 & 0.001 & $\mathrm{~V}(8)=0.21, \mathrm{p}<0.001$ \\
& electronic banking & 42.43 & 8 & 0.001 & $\mathrm{~V}(8)=0.25, \mathrm{p}<0.001$ \\
\hline education & checking and saving account & 20.65 & 6 & 0.002 & $\mathrm{~V}(6)=0.17, \mathrm{p}<0.01$ \\
& commercial credit & 13.47 & 6 & 0.036 & $\mathrm{~V}(6)=0.13, \mathrm{p}<0.05$ \\
& fixed-term deposit & 19.03 & 6 & 0.004 & $\mathrm{~V}(6)=0.16, \mathrm{p}<0.01$ \\
& insurance & 17.33 & 6 & 0.008 & $\mathrm{~V}(6)=0.15, \mathrm{p}<0.05$ \\
& debit cards & 12.30 & 6 & 0.056 & none \\
& electronic banking & 33.79 & 6 & 0.001 & $\mathrm{~V}(6)=0.21, \mathrm{p}<0.001$ \\
\hline period & checking and saving account & 12.64 & 4 & 0.013 & $\mathrm{~V}(4)=0.13, \mathrm{p}<0.05$ \\
of registration at & commercial credit & 9.87 & 4 & 0.043 & $\mathrm{~V}(4)=0.12, \mathrm{p}=0.055$ \\
the Labour Office & fixed-term deposit & 13.37 & 4 & 0.010 & $\mathrm{~V}(4)=0.13, \mathrm{p}<0.05$ \\
& insurance & 14.26 & 4 & 0.006 & $\mathrm{~V}(4)=0.14, \mathrm{p}<0.01$ \\
& debit cards & 12.36 & 4 & 0.015 & $\mathrm{~V}(4)=0.13, \mathrm{p}<0.05$ \\
reasons for reg- & electronic banking & 16.88 & 4 & 0.002 & $\mathrm{~V}(4)=0.15, \mathrm{p}<0.01$ \\
\hline bour Office & checking and saving account & 31.49 & 10 & 0.001 & $\mathrm{~V}(10)=0.20, \mathrm{p}<0.01$ \\
& commercial credit & 24.72 & 10 & 0.006 & $\mathrm{~V}(10)=0.17, \mathrm{p}<0.05$ \\
& fixed-term deposit & 29.99 & 10 & 0.001 & $\mathrm{~V}(10)=0.18, \mathrm{p}<0.01$ \\
& insurance & 22.67 & 10 & 0.012 & $\mathrm{~V}(10)=0.16, \mathrm{p}=0.055$ \\
& debit cards & 33.52 & 10 & 0.001 & $\mathrm{~V}(10)=0.20, \mathrm{p}<0.01$ \\
& electronic banking & 33.66 & 10 & 0.001 & $\mathrm{~V}(10)=0.20, \mathrm{p}<0.01$ \\
\hline & & & &
\end{tabular}

Notes:

$\chi$ — likelihood function, $\mathrm{df}$ - number of liberty degrees, $\mathrm{p}$ - statistical validity.

Source: Own study. 
Table 2.

Opinion of the unemployed on saving money for the future

\begin{tabular}{lcc}
\hline Is it worth saving money for the future? & Number of people & Group percentage \\
\hline absolutely yes & 215 & 61.4 \\
rather yes & 97 & 27.7 \\
rather not & 12 & 3.4 \\
absolutely not & 3 & 0.9 \\
hard to say & 21 & 6.0 \\
no data & 2 & 0.6 \\
overall & 350 & 100 \\
\hline
\end{tabular}

Source: Own study.

Table 3.

Services that bank refused to respondents

\begin{tabular}{lcc}
\hline \multicolumn{1}{c}{ Institutions } & Number of people & Group percentage \\
\hline bank credit & 87 & 24.9 \\
loan & 68 & 19.4 \\
creating a bank account & 13 & 3.7 \\
payment card issuance & 12 & 3.4 \\
overall & 180 & 51.4 \\
\hline
\end{tabular}

Source: Own study.

Chart 1.

Use of the banking services and variables such as age, education and respondent length of time registered in Labour Office (\%)

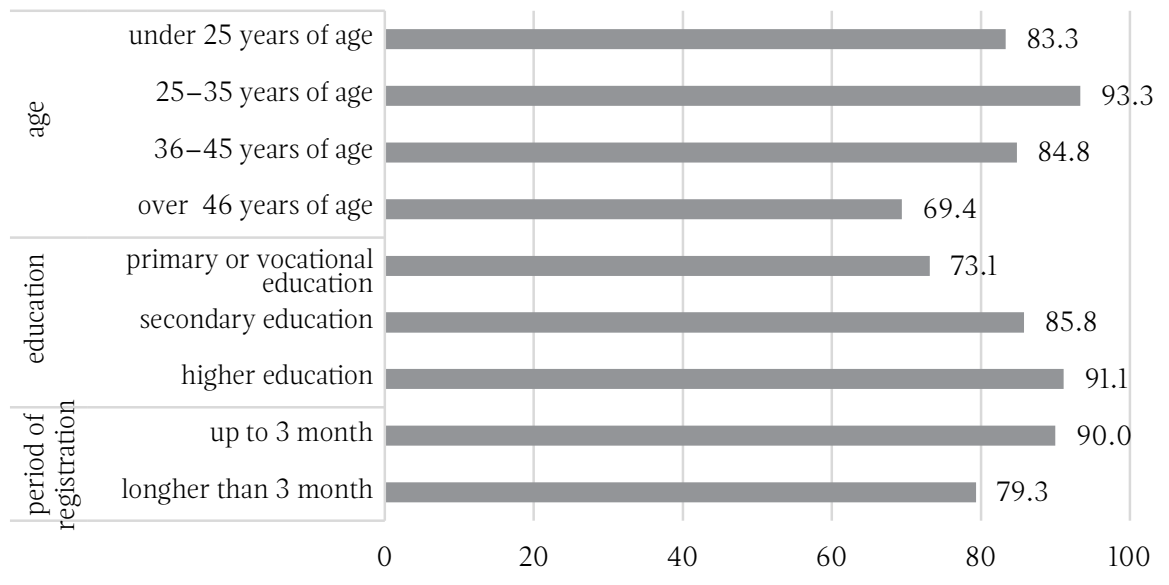

Source: Own study. 


\section{Chart 2.}

Opinions of the respondents on saving money for the future and education (\%)

80 71.1

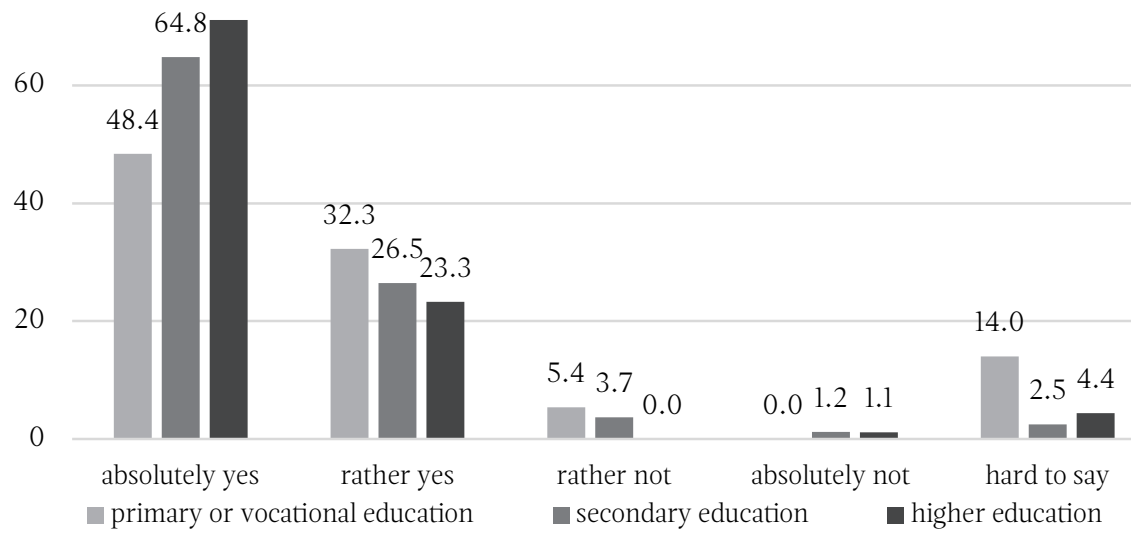

Source: Own study.

\section{Chart 3.}

Refusal to provide banking services and age and education (\%)

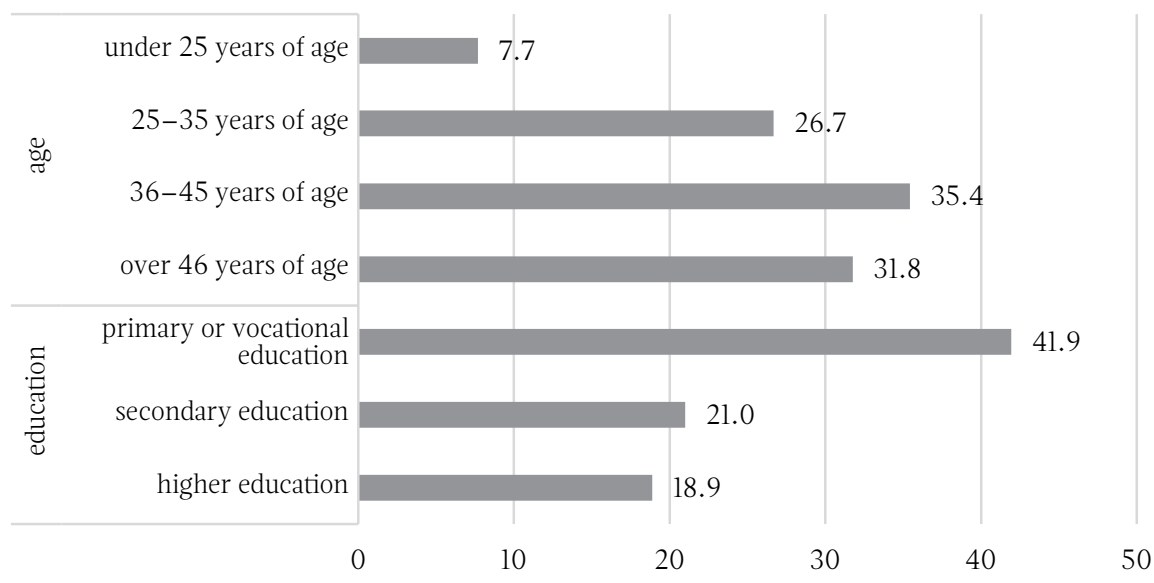

Source: Own study. 


\section{Chart 4.}

Banking service refusals and education of the respondents (\%)

40 34.4

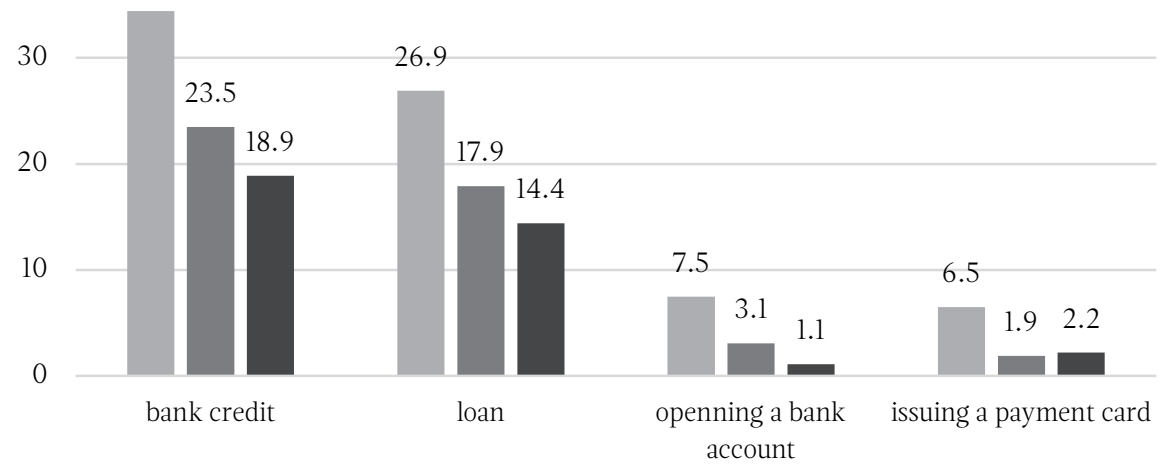

$$
\text { - primary or vocational education } \quad \text { secondary education } \quad \text { higher education }
$$

Source: Own study.

\section{Chart 5.}

Refusal of banking services and a reason for registering at Labour Office (\%)

35

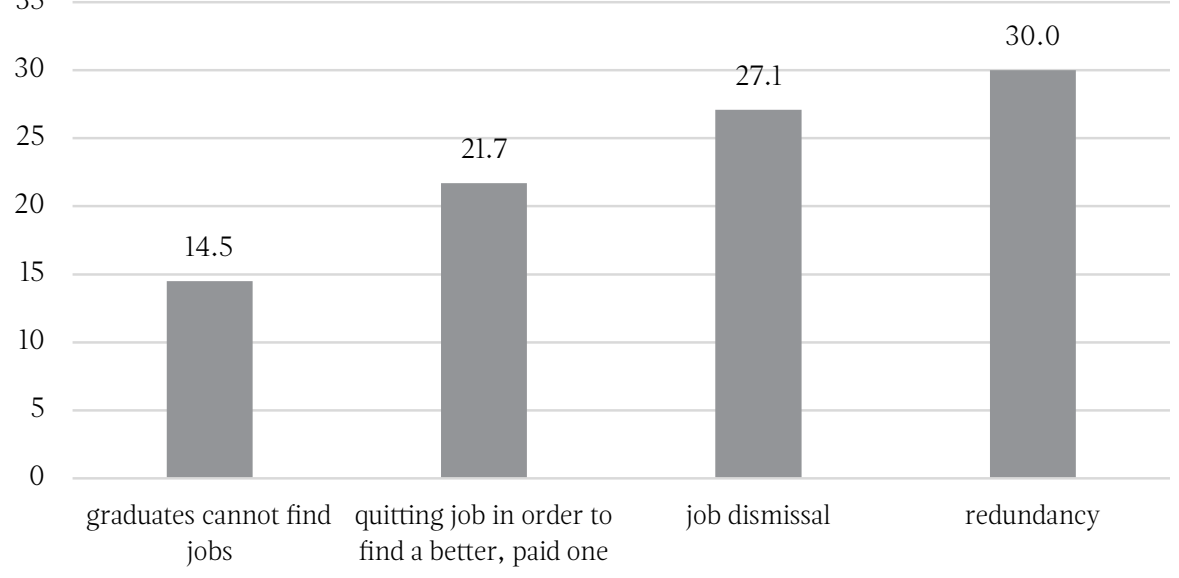

Source: Own study. 


\section{Scheme 1 .}

Levels of banking penetrations

\begin{tabular}{|l|l|l|}
\hline level I & for people who do not use banking services at all (unbanked) \\
\hline level II & $\begin{array}{l}\text { for people who have a bank account and payment card, but do not use other services } \\
\text { (marginally banked) }\end{array}$ \\
\hline
\end{tabular}

Source: Own preparation based on Kuchciak (2012). 
